\title{
JKEP
}

Vol 5, No 2, November 2020

ISSN: 2354-6042 (Print)

ISSN : 2354-6050 (Online)

\section{Peran Aplikasi Seluler terhadap Peningkatan Informasi Imunisasi Anak Bagi Orang Tua: Studi Literatur}

\author{
Astuti' La Ode Abdul Rahman \\ Fakultas Ilmu Keperawatan, Universitas Indonesia \\ email: astutiutik21@gmail.com
}

\author{
Artikel history \\ Dikirim, Dec 10 ${ }^{\text {th }}, 2019$ \\ Ditinjau, May $9^{\text {th }}, 2020$ \\ Diterima, Mei $1^{\text {st }}, 2020$
}

\begin{abstract}
Immunization is important for children because it can prevent various infectious diseases that can inhibit a child's growth and development. The provision of immunization in children is often found various obstacles caused by the target of immunization cannot be achieved. This can be caused due to a lack of information and immunization schedule errors due to the many types of immunizations with different schedules. As technology develops, various health-related cellular applications emerge called mhealth. Mhealth related to immunization is expected to increase information for parents so they can provide immunizations for their children as recommended. The purpose of this study is to determine the role of mobile applications related to immunization in increasing immunization information for parents. Literature is collected for review, literature search uses several online databases that are included in the inclusion criteria and is limited to 2015-2020. Nine articles are used as the main analysis, other articles are added to support the discussion. Cellular applications related to immunization are available in various forms. Overall, these applications have a major role in providing information about immunization knowledge and immunization schedule information to increase parental participation to provide immunizations to their children in full. Therefore, health workers, especially those directly related to child immunization, are advised to encourage the use of mobile applications related to immunization against parents in order to achieve goals related to immunization in children.

Keywords: Children Immunization; Mobile Applications; MHealth; Literature review
\end{abstract}

\begin{abstract}
ABSTRAK
Imunisasi penting bagi anak karena dapat mencegah berbagai penyakit infeksius yang dapat menghambat pertumbuhan dan perkembangan anak. Pemberian imunisasi pada anak sering ditemukan berbagai kendala sehingga target imunisasi tidak dapat tercapai. Hal tersebut dapat disebabkan karena kekurangan informasi dan kesalahan jadwal imunisasi akibat banyaknya macam imunisasi dengan jadwal yang berbeda. Seiring berkembangnya teknologi, muncul berbagai macam aplikasi seluler terkait kesehatan yang dinamakan MHealth. MHealth terkait imunisasi diharapkan dapat menambah informasi bagi orang tua sehingga dapat memberikan imunisasi untuk anaknya sesuai yang dianjurkan. Tujuan telaah artikel ini adalah untuk mengetahui peranan aplikasi seluler terhadap peningkatan informasi imunisasi pada anak bagi orang tua. Literatur dikumpulkan untuk ditelaah, pencarian literatur menggunakan beberapa
\end{abstract}


database online yang masuk dalam kriteria inklusi dan dibatasi tahun 2015-2020 Sembilan artikel dijadikan analisis utama, ditambahkan artikel lainnya sebagai pendukung pembahasan. Aplikasi seluler terkait imunisasi tersedia dalam berbagai macam bentuk. Secara keseluruhan, aplikasi-aplikasi tersebut mempunyai peran utama dalam memberikan informasi mengenai pengetahuan imunisasi maupun informasi jadwal imunisasi sehingga dapat meningkatkan partisipasi orang tua untuk memberikan imunisasi pada anaknya secara lengkap. Oleh sebab itu, tenaga kesehatan terutama yang berkaitan langsung dengan imunisasi anak disarankan untuk menggalakkan penggunaan aplikasi seluler terkait imunisasi terhadap orang tua sehingga tujuan-tujuan terkait imunisasi pada anak dapat tercapai.

Kata Kunci: Imunisasi pada anak; Aplikasi Seluler; MHealth; Studi Literatur

\section{PENDAHULUAN}

Imunisasi adalah sebuah proses untuk meningkatkan kekebalan tubuh anak dengan pemberian zat imunobiologis (Havaso, Mulyadi, \& Suratno, 2019). Proses ini dapat diberikan secara aktif maupun pasif, imunisasi aktif adalah produksi antibodi atau respon daya tahan tubuh lainnya melalui pemberian vaksin atau toksoid sedangkan imunisasi pasif adalah pemberian zat kekebalan sementara menggunakan antibodi dari tubuh yang telah terbentuk sebelumnya (Kroger, Duchin, \& Vázquez, 2018). Vaksinasi adalah standar perawatan sebagai bagian dari pemeliharaan kesehatan untuk orang sehat dan untuk pasien dengan berbagai kondisi medis (Khasnis, 2015). Dari pengertian tersebut dapat dilihat bahwa pengertian imunisasi tidak sama dengan vaksin, vaksin merupakan bagian dari imunisasi, sehingga penggunaan kata imunisasi merujuk pada pengertian yang lebih luas tentang proses penambahan zat atau pemberian vaksin untuk meningkatkan daya tahan tubuh.

Anak yang mendapatkan imunisasi akan mendapatkan berbagai keuntungan baik dari segi fisik anak tersebut maupun keuntungan dari sisi keluarganya. Centers for Disease Control and Prevention (CDC) merekomendasikan vaksin yang rutin dapat mencegah 17 penyakit yang terjadi pada bayi, anak, remaja, dan orang dewasa (Kroger et al., 2018). Vaksinasi mempunyai pengaruh besar untuk menjaga anak dari berbagai macam penyakit infeksius (Bhatti, Huang, Wanghttps, Mehmood, \& Di, 2018). Vaksin dapat mereduksi pengeluaran sebanyak US\$1 miliar pada keluarga, jumlah tersebut sama dengan jumlah yang dikeluarkan apabila anak tidak diberikan vaksin dengan tepat (Atkinson et al., 2019). 
Kebalikan dari keuntungan yang didapatkan, anak-anak yang tidak diimunisasi menghadapi berbagai bahaya Terdapat lebih dari 19.4 juta anak-anak yang tidak divaksinasi, berisiko tinggi menghadapi kematian (Khader, Laflamme, Schmid, El-halabi, \& Abu, 2019). Di Kanada, dalam setiap tahunnya terdapat hampir 12.200 anak-anak dirawat di rumah sakit akibat penyakit influenza dan 3500 kematian akibat penyakit yang sebenarnya bisa dihindari melalui vaksin (Pfaeffli, White, Mitchell, \& Faulkner, 2019). World Health Organization (2017) melaporkan bahwa beberapa dekade yang lalu, hanya di India saja didapatkan 150.000-200.000 kasus tetanus pada bayi baru lahir.

Imunisasi di Indonesia sendiri diatur oleh Kementerian Kesehatan Republik Indonesia dan Ikatan Dokter Anak Indonesia (IDAI) melalui Satuan Tugas Imunisasi. Terdapat program imunisasi yang diwajibkan untuk anak dinamakan imunisasi dasar lengkap (Gunardi et al., 2017). Berdasarkan data dari Riset Kesehatan Dasar (Riskesdas) 2018 (Kementerian Kesehatan, 2018), presentase anak yang mengikuti imunisasi dasar secara lengkap menurun dari tahun 2018 dibandingkan pada tahun 2013, yaitu sebanyak 59,2\% pada tahun 2013 dan
$57,9 \%$ pada tahun 2018. Kenaikan presentase terjadi pada anak yang sama sekali tidak mendapatkan imunisasi dasar lengkap, sebanyak 8,7\% pada tahun 2013 dan 9,2\% pada tahun 2018 (Kementerian Kesehatan, 2018). Adanya penurunan tingkat imunisasi dan meningkatnya penundaan terhadap imunisasi secara tepat waktu dapat menciptakan lingkungan yang rentan terhadap penyakit yang sebenarnya bisa dicegah melalui imunisasi (Atkinson et al., 2016). Atkinson et al., (2019) mengidentifikasi alasan utama mengapa orang memilih untuk tidak vaksin atau menunda jadwal vaksin beberapa diantaranya adalah informasi yang tidak dapat dipercaya terkait imunisasi atau vaksin, alasan prosedur keamanan dari vaksin, jadwal personal yang sibuk, dan alasan tidak ada ingat karena jadwal vaksin yang terlalu banyak maupun bervariasi antar satu vaksin dengan vaksin lainnya. Alasan-alasan tersebut mengerucut pada satu hal yaitu informasi yang berkaitan dengan imunisasi secara umum maupun informasi pribadi terkait riwayat pemberian imunisasi masing-masing anak.

Pemberian imunisasi pada anak dapat ditingkatkan melalui berbagai pendekatan salah satunya melalui pendekatan teknologi. Intervensi teknologi memperlihatkan hasil 
yang menjanjikan berhubungan dengan ketepatan waktu terhadap vaksinasi (Atkinson et al., 2016). Penggunaan teknologi salah satunya adalah dengan memanfaatkan keberadaan perangkat seluler, karena perangkat seluler merupakan benda yang hampir setiap orang memilikinya dan mudah digunakan. Teknologi perangkat seluler dengan membuat suatu aplikasi untuk kepentingan vaksin merupakan satu langkah lebih maju terhadap perhatian mengenai vaksin (Bednarczyk, Frew, Salmon, Whitney, \& Omer, 2017). Sistem informasi imunisasi adalah sebuah hal kritis yang dapat meningkatkan kualitas dan mengevaluasi kesuksesan program imunisasi (Wilson, Atkinson, Deeks, \& Crowcroft, 2016). Perawat sebagai salah satu tenaga kesehatan perlu mengetahui perkembangan aplikasi seluler imunisasi terkait dengan efektifitasnya karena perawat dituntut untuk berperan aktif terhadap meningkatnya cakupan imunisasi dasar lengkap (Triana, 2016). Melihat berbagai permasalahan terkait imunisasi diatas, keberadaan aplikasi seluler terkait imunisasi diharapkan dapat menyelesaikan permasalahanpermasalahannya salah satunya permasalahan yang paling mendasar yaitu terkait informasi mengenai imunisasi. Oleh karena itu perlu dilakukan sebuah tinjauan khusus bagaimana kebermanfaatan aplikasiaplikasi seluler tersebut dalam memberikan manfaat terutama mengenai hal pemberian informasi kepada orang tua sebagai pengguna aplikasi. Tujuan dari studi literatur ini adalah untuk melihat apakah aplikasi-aplikasi seluler terkait imunisasi yang tersedia sudah mampu memberikan informasi yang dibutuhkan orang tua sehingga orang tua dapat memberikan imunisasi secara lengkap kepada anaknya.

\section{METODE}

Metode penelitian artikel menggunakan metode penelusuran literatur melalui database online. Adapun database online yang digunakan adalah Science Direct, OXFORD University Press, Springer Link, SAGE journals, Wiley Online Library, dan Google Scholar. Kata kunci yang digunakan dalam pencarian artikel adalah "mobile application" AND "vaccination" OR "immunization" untuk artikel berbahasa Inggris dan "vaksin”, “anak", "Indonesia", "aplikasi seluler" untuk artikel berbahasa Indonesia. Filter yang digunakan yaitu jenis artikel merupakan artikel penelitian atau research article dan artikel diterbitkan antara tahun 2015-2020. Tahapan yang dilakukan dalam penentuan artikel yang ditelaah tergambar dalam gambar 1 dibawah ini. Berdasarkan kata kunci yang 
dimasukkan ke dalam masing-masing database diperoleh sebanyak 3710 artikel. Langkah pertama yang digunakan adalah membaca sekilas judul dan abstrak dan disortir yang tidak sesuai topik sebanyak 102. Langkah selanjutnya adalah membaca skrining full text dan ditemukan 54 artikel yang sesuai. Langkah terakhir adalah skrining sesuai kriteria inklusi. Adapun kriteria inklusi yang digunakan adalah penelitian aplikasi digunakan oleh orang tua bukan penyedia layanan kesehatan dan aplikasi seluler imunisasi dapat digunakan untuk imunisasi pada anak. Kriteria eksklusi yang digunakan adalah artikel-artikel berupa tinjauan literatur dan artikel penelitian bukan merupakan artikel proposal. Hasil akhir didapatkan 9 artikel studi literatur.

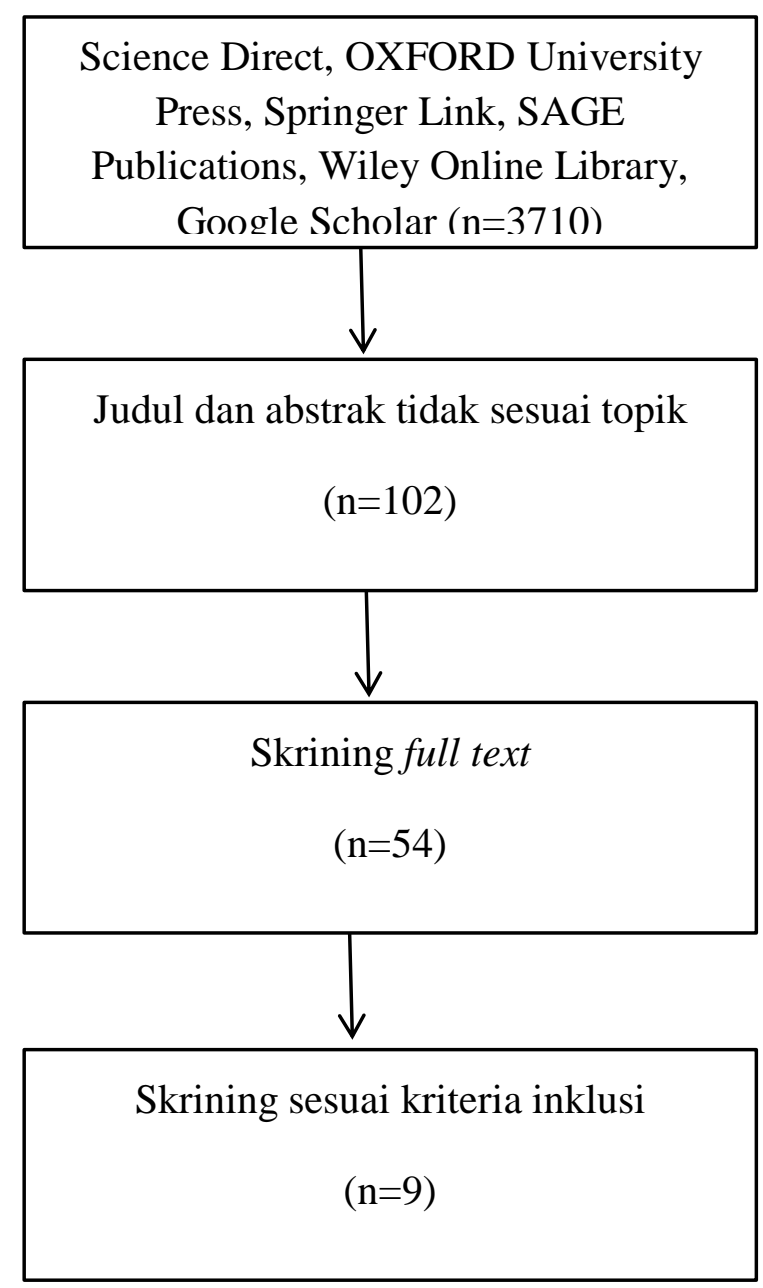

Gambar 1. Alur telaah artikel

\section{HASIL DAN PEMBAHASAN}

Mobile Health (Mhealth) dideskripsikan oleh WHO sebagai bentuk dukungan terhadap praktik kedokteran dan kesehatan masyarakat yang didukung oleh perangkat seluler termasuk telepon genggam dan 
tablet, baik dengan memanfaatkan fiturfitur yang sudah ada atau dengan pemanfaatan aplikasi seluler. Aplikasi terkait medis dan kesehatan dapat dibuat dengan mudah oleh ahlinya dan menargetkan pasien mencapai derajat pasien sadar literasi kesehatan (Wilson et al., 2016). MHealth dalam bentuk aplikasi seluler dimanfaatkan untuk kesukesan imunisasi pada anak. Fitur yang disediakan berbagai aplikasi imunisasi yaitu menyediakan informasi terkait imunisasi, menyediakan jadwal vaksin yang dapat disesuaikan dengan waktu pengguna aplikasi, mengidentifikasi lokasi klinik yang menyediakan layanan vaksin, dan menyediakan hal-hal lain terkait pendidikan vaksin (Wilson et al., 2015).

Tabel 1. Hasil Analisis Artikel

\begin{tabular}{|c|c|c|c|}
\hline $\begin{array}{l}\text { Penulis (Tahun } \\
\text { Publikasi } \\
\text { Artikel) }\end{array}$ & $\begin{array}{c}\text { Tempat } \\
\text { Penelitian }\end{array}$ & Aplikasi seluler yang Digunakan & Hasil Penelitian \\
\hline $\begin{array}{l}\text { Pfaeffli, L., } \\
\text { White, L., } \\
\text { Mitchell, M., } \\
\text { \& Faulkner, } \\
\text { G. (2019). }\end{array}$ & $\begin{array}{l}\text { British } \\
\text { Colum } \\
\text { bia, } \\
\text { Kanada }\end{array}$ & $\begin{array}{l}\text { Carrot Rewards App, sebuah } \\
\text { aplikasi seluler yang berfokus } \\
\text { pada perubahan perilaku } \\
\text { kesehatan. Pengguna dapat } \\
\text { mengikuti kuis mengenai vaksin, } \\
\text { setelah mengikuti kuis pengguna } \\
\text { mendapatkan poin yang dapat } \\
\text { digunakan untuk belanja, tiket } \\
\text { menonton, dan lain-lain. Setelah } \\
\text { itu pengguna akan mendapatkan } \\
\text { notifikasi dari apoteker terdekat } \\
\text { untuk mendapatkan vaksin } \\
\text { influenza. }\end{array}$ & $\begin{array}{l}\text { Penelitian ini melaporkan } \\
\text { bahwa aplikasi } \\
\text { smartphone berdasarkan } \\
\text { pemberian poin dapat } \\
\text { memberikan hasil yang } \\
\text { bermakna terkait } \\
\text { ketertarikan pengguna } \\
\text { untuk mendapatkan } \\
\text { materi pendidikan atau } \\
\text { informasi mengenai } \\
\text { vaksin dan mendapatkan } \\
\text { vaksin influenza }\end{array}$ \\
\hline $\begin{array}{l}\text { Atkinson, K. } \\
\text { M., } \\
\text { Westeinde, J., } \\
\text { Ducharme, } \\
\text { R., Sarah, E., } \\
\text { Deeks, S. } \\
\text { L., Crowcroft, } \\
\text { N., Can, K. } \\
\text { W. (2016). }\end{array}$ & $\begin{array}{c}\text { Kan } \\
\text { ada }\end{array}$ & $\begin{array}{l}\text { Immunize CA, aplikasi imunisasi } \\
\text { seluler yang menyediakan } \\
\text { informasi mengenai vaksin untuk } \\
\text { dirinya sendiri dan keluarganya, } \\
\text { menyajikan pengingat jadwal } \\
\text { vaksin dan, memperingatkan } \\
\text { pengguna apabila pengguna } \\
\text { sedang berada di suatu daerah } \\
\text { dengan } \\
\text { wabah penyakit tertentu dan } \\
\text { pengguna diharuskan untuk } \\
\text { menerima vaksin sesuai penyakit } \\
\text { tersebut. }\end{array}$ & $\begin{array}{l}62 \% \text { responden } \\
\text { mengatakan bahwa } \\
\text { mereka mengandalkan } \\
\text { aplikasi ini untuk mencari } \\
\text { segala informasi } \\
\text { mengenai imunisasi tanpa } \\
\text { harus melihat sumber } \\
\text { yang lain. }\end{array}$ \\
\hline $\begin{array}{l}\text { Bednarczyk, R. } \\
\text { A., Frew, } \\
\text { P. M., } \\
\text { Salmon, D. } \\
\text { A., Whitney, } \\
\text { E., \& Omer, }\end{array}$ & $\begin{array}{c}\text { US } \\
\text { A }\end{array}$ & $\begin{array}{l}\text { ReadyVax, sebuah aplikasi seluler } \\
\text { yang menyediakan informasi } \\
\text { mengenai vaksin yang terpercaya } \\
\text { dan berdasarkan bukti-bukti } \\
\text { ilmiah, ditargetkan untuk para } \\
\text { penyedia layanan kesehatan, }\end{array}$ & $\begin{array}{l}\text { ReadyVax terbukti efektif } \\
\text { digunakan sebagai } \\
\text { sumber primer dalam } \\
\text { mendapatkan informasi } \\
\text { mengenai vaksin }\end{array}$ \\
\hline
\end{tabular}




\begin{tabular}{|c|c|c|c|}
\hline S. B. (2017). & & $\begin{array}{l}\text { apoteker, dan pasien (termasuk } \\
\text { orang tua untuk pemantauan } \\
\text { vaksin anaknya) }\end{array}$ & \\
\hline $\begin{array}{l}\text { Fadda, M., } \\
\text { Galimberti, E., } \\
\text { Fiordelli, M., } \\
\text { Romanò, L., } \\
\text { Zanetti, A.S., } \\
\text { Peter J.F., Marta } \\
\text { G., Elisa, F., } \\
\text { (2017) }\end{array}$ & $\begin{array}{c}\text { Ital } \\
\mathrm{y}\end{array}$ & $\begin{array}{l}\text { Morbiquiz, sebuah aplikasi seluler } \\
\text { yang dirancang oleh ahli } \\
\text { komunikasi kesehatan, mHealth, } \\
\text { dan psikolog. Aplikasi ini } \\
\text { dirancang dalam bentuk } \\
\text { permainan seluler yang dipenuhi } \\
\text { dengan animasi menarik, dimana } \\
\text { tujuannya adalah untuk } \\
\text { meningkatkan pengetahuan dan } \\
\text { memberdayakan orang tua dalam } \\
\text { memberikan vaksin MMR } \\
\text { terhadap anaknya. }\end{array}$ & $\begin{array}{lr}\text { Penelitian } & \text { ini } \\
\text { membuktikan bahwa } \\
\text { aplikasi seluler yang } \\
\text { dirancang } \\
\text { meningkatkan } \\
\text { pengetahuan orang tua } \\
\text { tentang vaksin MMR } \\
\text { melalui informasi yang } \\
\text { diperoleh dari aplikasi } \\
\text { dengan sistem animasi } \\
\text { dan permainan. }\end{array}$ \\
\hline $\begin{array}{l}\text { Seeber, L., } \\
\text { Conrad, T., } \\
\text { Hoppe, C., } \\
\text { Obermeier, } \\
\text { P., Chen, X., } \\
\text { Karsch, K., } \\
\ldots . \\
\text { Rath, B. } \\
\text { (2017). }\end{array}$ & $\begin{array}{l}\text { Jer } \\
\text { man }\end{array}$ & $\begin{array}{l}\text { VaccApp, aplikasi ini } \\
\text { menampilkan bahasa visual yang } \\
\text { menyenangkan, menggunakan } \\
\text { gambar-gambar yang terkait } \\
\text { dengan petugas kesehatan dan } \\
\text { penerima vaksin sebagai avatar } \\
\text { dengan tujuan untuk membuat } \\
\text { pasien lebih tertarik mengenai } \\
\text { vaksin. Penerima vaksin dapat } \\
\text { mengikuti kuis interaktif dalam } \\
\text { aplikasi tersebut. }\end{array}$ & $\begin{array}{l}\text { Aplikasi seluler yang } \\
\text { mudah digunakan } \\
\text { mendorong orang tua } \\
\text { untuk lebih mengetahui } \\
\text { tentang vaksin. Orang tua } \\
\text { menjadi lebih termotivasi } \\
\text { untuk memberikan vaksin } \\
\text { secara tepat waktu kepada } \\
\text { anaknya. }\end{array}$ \\
\hline $\begin{array}{l}\text { Gatuha, G., \& } \\
\text { Jiang, T. } \\
\text { (2015). }\end{array}$ & $\begin{array}{c}\text { Ken } \\
\text { ya }\end{array}$ & $\begin{array}{l}\text { KenVACS, sistem yang ditujukan } \\
\text { kepada petugas kesehatan untuk } \\
\text { mengumpulkan data demografi } \\
\text { dan informasi vaksin pada pasien. } \\
\text { Informasi ini disimpan di small in- } \\
\text { built SQLite data base kemudian } \\
\text { dipindahkan secara online melalui } \\
\text { Wi-Fi. Pasien akan mendapatkan } \\
\text { jadwal mengenai vaksin otomatis } \\
\text { melalui SMS. }\end{array}$ & $\begin{array}{l}\text { Pasien merasakan } \\
\text { kebermanfaatan aplikasi } \\
\text { ini karena dapat } \\
\text { mengakses informasi } \\
\text { riwayat vaksin dan } \\
\text { mendapatkan pengingat } \\
\text { mengenai jadwal vaksin. }\end{array}$ \\
\hline $\begin{array}{l}\text { Gibson, D. G., } \\
\text { Ochieng, B., } \\
\text { Kagucia, E. } \\
\text { W., Were, J., } \\
\text { Hayford, K., } \\
\text { Moulton, L. } \\
\text { H., Feikin, D. } \\
\text { R. (2017) }\end{array}$ & $\begin{array}{c}\text { Ken } \\
\text { ya }\end{array}$ & $\begin{array}{l}\text { M-SIMU, The Mobile Solutions } \\
\text { for Immunization, sebuah sistem } \\
\text { pengingat vaksin yang diberikan } \\
\text { melalui SMS yang ditambahkan } \\
\text { dengan pemberian insentif } \\
\text { sebanyak } 200 \text { KES (mata uang } \\
\text { Kenya) }\end{array}$ & $\begin{array}{l}\text { Pengingat vaksin melalui } \\
\text { SMS dengan pemberian } \\
\text { insentif secara signifikan } \\
\text { dapat meningkatkan } \\
\text { cakupan imunisasi secara } \\
\text { tepat waktu. }\end{array}$ \\
\hline $\begin{array}{l}\text { Kumari, S., } \\
\text { Haripriya, A., } \\
\text { Aruna, A., } \\
\text { Vidya, D. S., } \\
\& \\
\text { Nithy, M. N. } \\
\text { (2017). }\end{array}$ & $\begin{array}{c}\text { Indi } \\
\mathrm{a}\end{array}$ & $\begin{array}{l}\text { Immunize, sebuah aplikasi seluler } \\
\text { yang menyediakan jadwal vaksin } \\
\text { wajib pada anak dihubungkan } \\
\text { dengan riwayat kesehatannya. }\end{array}$ & $\begin{array}{l}\text { Orang tua dapat } \\
\text { mengakses informasi } \\
\text { imunisasi anaknya dan } \\
\text { detail rekam medis } \\
\text { lainnya. }\end{array}$ \\
\hline
\end{tabular}




\begin{tabular}{|c|c|c|c|}
\hline & & & $\begin{array}{lr}\text { Perancangan } & \text { Aplikasi } \\
\text { Pengingat } & \text { Jadwal } \\
\text { Imunisasi di } & \text { Puskesmas }\end{array}$ \\
\hline $\begin{array}{l}\text { Havaso, A. T., } \\
\text { Mulyadi, \& } \\
\text { Suratno, E. } \\
(2019) .\end{array}$ & $\begin{array}{c}\text { Indonesia } \\
\text { (Puskesmas } \\
\text { Kebun } \\
\text { Handil Kota } \\
\text { Jambi) }\end{array}$ & $\begin{array}{l}\text { Aplikasi Pengingat Jadwal } \\
\text { Imunisasi, digunakan sebagai } \\
\text { pengingat jadwal imunisasi yang } \\
\text { dikembangkan berbasis android, } \\
\text { bertujuan informasi tentang } \\
\text { imunisasi, penjelasan berbagai } \\
\text { kejadian paska imunisasi, dan } \\
\text { lokasi praktek dokter yang } \\
\text { terdekat dari lokasi pengguna. }\end{array}$ & $\begin{array}{l}\text { Kebun Handil Kota Jambi } \\
\text { dapat membantu untuk } \\
\text { mengingat jadwal } \\
\text { imunisasi, menampilkan } \\
\text { informasi imunisasi serta } \\
\text { tumbuh kembang anak, } \\
\text { dan memberikan } \\
\text { petunjuk tentang praktek } \\
\text { dokter yang terdekat dari } \\
\text { lokasi pengguna aplikasi } \\
\text { untuk memperoleh } \\
\text { layanan imunisasi. }\end{array}$ \\
\hline
\end{tabular}

Telaah beberapa hasil penelitian menyebutkan bahwa Mhealth imunisasi ada yang menggunakan bantuan SMS sebagai fitur pengingat vaksin, hal tersebut didapatkan di negara-negara berpenghasilan rendah dan menengah dimana teknologi wireless masih tergolong mahal (Domek et al., 2018).

Penelitian menunjukkan terdapat berbagai aplikasi yang dapat dimanfaatkan untuk vaksin termasuk imunisasi pada anak. Tabel 1. memberi gambaran mengenai jenis aplikasi yang dapat dimanfaatkan untuk kemajuan imunisasi pada anak dan hasil penelitiannya. Pada telaah artikel ini didapatkan 10 macam aplikasi seluler. Penelitian terhadap aplikasi seluler tersebut tersebar di berbagai negara. Ada satu aplikasi, yang saat ini masih dalam penelitian yaitu Children Immunization App (CImA), aplikasi tersebut merupakan pilot project di Jordan. 10 aplikasi seluler mempunyai kesamaan berupa pemberian informasi mengenai vaksin. Pemberian informasi dilakukan dengan melalui kuis atau melalui informasi berupa narasi. 8 artikel menyatakan bahwa aplikasi yang digunakan terdapat fitur pengingat jadwal vaksin, diharapkan pengguna aplikasi dapat melakukan vaksin tepat waktu. Terdapat 2 aplikasi seluler yang dalam pemanfaatannya menggandeng fitur Short Message Services (SMS) sebagai pengingat jadwal vaksin yaitu KenVacs dan M-SIMU yang samasama diteliti di Kenya.

Tabel 1 menggambarkan bahwa 8 dari 10 pemanfaatan aplikasi seluler membawa dampak positif terhadap kemajuan imunisasi atau vaksin. Terdapat 2 aplikasi yang memberikan hadiah ke pengguna aplikasi apabila melakukan vaksin yaitu aplikasi Carrot Rewards App dan MSIMU, dilaporkan bahwa melalui fitur 
tersebut pengguna tertarik untuk mendapatkan materi pendidikan mengenai vaksin (Pfaeffli et al., 2019). Aplikasi sejenis yang cukup dirasa penggunanya menarik adalah aplikasi berbasis game dimana penggunanya merasa teredukasi dengan baik tentang imunisasi MMR (Fadda et al., 2017).

Penggunaan aplikasi seluler untuk imunisasi meningkatkan ketepatan waktu imunisasi pada anak-anak. Melalui pemberdayaan individu untuk mempunyai kontrol terhadap diri sendiri berhubungan dengan riwayat status imunisasi anakanaknya, menggunakan perangkat seluler dapat meningkatkan ketepatan waktu dan keakuratan data pada pusat sistem informasi imunisasi (Wilson et al., 2016). Hal tersebut sejalan dengan penelitian Atkinson et al., (2016) bahwa 1 dari 3 partisipan menyatakan penggunana aplikasi seluler untuk imunisasi secara konsisten meningkatkan ketepatan waktu pemberian imunisasi pada anak-anak mereka.

Adanya fitur pengingat jadwal vaksin yang terdapat pada sebagian aplikasi berdampak positif terhadap peningkatan capaian vaksin. Aplikasi-aplikasi yang berbeda dan sistem peringatan melalui SMS memperlihatkan hasil yang menjanjikan terhadap meningkatnya tingkat partisipasi individu terhadap imunisasi (Seeber et al., 2017). Atkinson et al., (2019) sependapat dengan hasil tersebut dengan menyatakan bahwa ide penggunaan teknologi digital melalui pemanfaatan aplikasi seluler merupakan hal yang sangat berguna terhadap peningkatan capaian imunisasi. Burgess et al., (2016) menyatakan bahwa sebagian besar penggunan aplikasi ImmunizeCA memiliki ketertarikan terbesar terhadap fitur pengingat jadwal imunisasi. Fitur pengingat vaksin melalui SMS secara signifikan berpengaruh positif terhadap perilaku mencari informasi kesehatan, meningkatkan pencapaian imunisasi di daerah Sub-Saharan Afrika, dan jumlah cakupan imunisasi di USA meningkat (Gibson et al., 2017).

Manfaat aplikasi seluler dirasakan pula oleh penyedia layanan kesehatan dan petugas kesehatan. Aplikasi KenVACS terbukti memberikan manfaat terhadap petugas kesehatan berupa efisiensi dan penghematan waktu dalam menyimpan data terkait imunisasi (Gatuha \& Jiang, 2015). Peningkatan modifikasi aplikasi seluler untuk imunisasi dapat membantu mencapai tujuan-tujuan individu, penyedia layanan kesehatan, dan kesehatan masyarakat untuk mempunyai akses yang 
satu pintu terhadap sistem informasi imunisasi (Wilson et al., 2016).

Penelitian mengenai penggunaan aplikasi seluler di Indonesia tidak begitu banyak ditemukan, akan tetapi Indonesia telah turut menggunakan aplikasi ini. Satu diantara artikel yang ditelaah memberikan informasi bahwa terdapat aplikasi seluler imunisasi yang diuji coba bernama Aplikasi Pengingat Jadwal Imunisasi (Havaso et al., 2019). Penelitian tersebut tidak melihat efektifitas penggunaan aplikasi terhadap pengguna dan tidak diuji cobakan secara nasional. Dilansir dari artikel lain, Ikatan Dokter Anak Indonesia (IDAI) ternyata telah memiliki aplikasi seluler terkait tumbuh kembang anak dimana terdapat fitur mengenai jenis imunisasi, jadwal imunisasi, dan pengingat imunisasi yang dapat digunakan secara nasional disebut PrimaKU (Paputungan \& Setiaji, 2019). Sejauh pengetahuan penulis, penelitian mengenai penggunaan PrimaKU tidak ditemukan, hal ini dapat dijadikan area penelitian selanjutnya.

Telaah artikel ini memiliki beberapa kekuatan dan kelemahan. Artikel yang ditelaah telah mewakili beberapa contoh penggunaan aplikasi seluler terkait imunisasi baik di negara-negara maju
(Kanada, USA, dan Jerman) dan negaranegara berkembang (Kenya, India, Jordan, dan Indonesia). Semua artikel yang ditelaah merupakan artikel-artikel terbaru dengan batasan lima tahun waktu publikasi, sehingga kemutakhiran ilmu dapat dipertanggungjawabkan. Namun, penelitian yang ditelaah pada masing-masing artikel mempunyai desain terbagi menjadi dua hal yang berbeda yaitu penelitian yang meneliti keefektifan terhadap penggunaan aplikasi seluler dan penelitian yang membahas mengenai aplikasinya.

\section{SIMPULAN}

Secara keseluruhan, teknologi berbasis aplikasi seluler memberikan manfaat terhadap imunisasi pada anak. Beberapa manfaat aplikasi seluler imunisasi terhadap imunisasi pada anak yang didapatkan dari telaah artikel berupa lebih terpaparnya pengguna aplikasi terhadap informasi imunisasi, meningkatkan ketepatan waktu imunisasi, fitur pengingat jadwal vaksin yang terdapat pada sebagian aplikasi berdampak positif terhadap peningkatan capaian vaksin, dan efisiensi manajemen yang dirasakan oleh penyedia layanan kesehatan. Dengan adanya berbagai aplikasi seluler terkait imunisasi, perawat dan tenaga keseahtan lainnya dapat berperan aktif untuk mengajak masyarakat menggunakan 
aplikasi yang ada sehingga tercapai target imunisasi yang diinginkan. Adapun aplikasi yang telah tersedia saat ini sebaiknya diedukasikan secara optimal oleh perawat dan tenaga kesehatan lainnya sehingga masyarakat mengetahui keberadaannya dan dapat menggunakannya. Selain itu diharapkan penggunaan dan efektivitas aplikasi seluler terkait imunisasi lebih digencarkan lagi penelitiannya di Indonesia, supaya dapat digunakan oleh masyarakat luas dan dirasakan manfaatnya.

\section{UCAPAN TERIMA KASIH}

Terima kasih kepada seluruh pihak yang telah membantu dalam penyusunan naskah studi literatur ini.

\section{DAFTAR RUJUKAN}

Atkinson, K. M. et al. (2016) 'Can mobile technologies improve on-time vaccination? A study piloting maternal use of ImmunizeCA , a PanCanadian immunization app', Human Vaccines \& Immunotherapeutics. Taylor \& Francis, 12(10), pp. 2654 2661. doi: 10.1080/21645515.2016.1194146.

Atkinson, K. M. et al. (2019) 'Effectiveness of digital technologies at improving vaccine uptake and series completion - A systematic review and metaanalysis of randomized controlled trials', Vaccine. Elsevier Ltd, 37(23), pp. 3050-3060. doi: 10.1016/j.vaccine.2019.03.063.
Bahri, S. and Hidayatullah, T. (2018) 'Penerapan Coloring Graph pada Sistem Pengingat dan Penjadwalan Imunisasi Dasar Lengkap', CESS (Journal of Computer Engineering System and Science, 3(2), pp. 128133.Bednarczyk, R. A. et al. (2017) 'ReadyVax: A new mobile vaccine information app', Human Vaccines and Immunotherapeutics. Taylor \& Francis, 13(5), pp. 1149-1154. doi: 10.1080/21645515.2016.1263779.

Bhatti, U. A. et al. (2018) 'Recommendation system for immunization coverage and monitoring', Human Vaccines \& Immunotherapeutics, 5515. doi: 10.1080/21645515.2017.1379639.Bu rgess, K. et al. (2016) 'Barriers and facilitators to the use of an immunization application: a qualitative study supplemented with Google Analytics data', Journal of Public Health, pp. 1-9. doi: 10.1093/pubmed/fdw032.

Domek, G. J. et al. (2018) 'Characteristics of mobile phone access and usage in rural and urban Guatemala : assessing feasibility of text message reminders to increase childhood immunizations', mHealth. doi: 10.21037/mhealth.2018.03.05.

Fadda, M., Galimberti, E., Fiordelli, M., Romanò, L., Zanetti, A., Schulz, P. J., Fadda, M., Galimberti, E., Fiordelli, M., \& Romanò, L. (2017). Effectiveness of a smartphone app to increase parents, knowledge and empowerment in the MMR vaccination decision: A randomized controlled trial. Human Vaccines \& Immunotherapeutics, 13(11), 25122521.

https://doi.org/10.1080/21645515.201 $\underline{7.1360456}$ 
Gatuha, G. and Jiang, T. (2015) 'KenVACS : Improving Vaccination of Children through Cellular Network Technology in Developing Countries', Interdisciplinary Journal of Information, Knowledge, and Management, 10, pp. 37-46.

Gibson, D. G. et al. (2017) 'Mobile phonedelivered reminders and incentives to improve childhood immunisation coverage and timeliness in Kenya ( MSIMU ): a cluster randomised controlled trial', The Lancet Global Health. Elsevier Ltd., 5(4), pp. e428e438. doi: 10.1016/S2214109X(17)30072-4.

Gunardi, H. et al. (2017) 'Jadwal Imunisasi Anak Usia 0 - 18 tahun Rekomendasi Ikatan Dokter Anak Indonesia 2017', 18(5), pp. 417-422.Havaso, A. T., Mulyadi and Suratno, E. (2019) 'Aplikasi Pengingat Jadwal Imunisasi pada Puskesmas Kebun Handil Kota Jambi Berbasis Android', 2(2), pp. 60-65.

Khader, Y. S. et al. (2019) 'Children Immunization App ( CImA ) Among Syrian Refugees in Zaatari Camp, Jordan: Protocol for a Cluster Randomized Controlled Pilot Trial Intervention Study Corresponding Author':, 8, pp. 1-8. doi: 10.2196/13557.Khasnis, A. (2015) 'Vaccination: Special populations are not all the same', Cleveland Clinic Journal of Medicine, 82(6), pp. 348349. doi: 10.3949/ccjm.82a.14137.

Kroger, A. T., Duchin, J. and Vázquez, M. (2018) 'General Best Practice Guidelines for Immunization. Best Practices Guidance of the Advisory Committee on Immunization Practices (ACIP)'. Available at: www.cdc.gov/vaccines/recs/storage/t oolkit/default.htm.

Kumari, S. et al. (2017) 'Immunize - Baby steps for smart healthcare: Smart solutions to child vaccination', 2017 International Conference on Innovations in Green Energy and Healthcare Technologies (IGEHT). doi: 10.1109/IGEHT.2017.8094048.

Oliver-williams, C. et al. (2017) 'Using Mobile Phones to Improve Vaccination Uptake in 21 Low- and Middle-Income Countries : Systematic Review Corresponding Author':, 5, pp. 1-15. doi: 10.2196/mhealth.7792.

Paputungan, I. V and Setiaji, H. (2019) 'Engineering kids health monitoring system in Indonesia'. doi: 10.1088/1757-899X/482/1/012040.

Pfaeffli, L. et al. (2019) 'Smartphone app uses loyalty point incentives and push notifications to encourage influenza vaccine uptake', Vaccine. Elsevier Ltd, 37(32), pp. 4594-4600. doi: 10.1016/j.vaccine.2018.04.018.

Qazi, U. et al. (2019) 'Compliance to timely vaccination in an Expanded Program on Immunization center of Pakistan', Vaccine. Elsevier Ltd, 37(32), pp. 4618-4622. doi: 10.1016/j.vaccine.2018.01.044.

Rath, B. et al. (2019) 'Partnering for enhanced digital surveillance of influenza - like disease and the effect of antivirals and vaccines ( PEDSIDEA )', Influenza and Other Respiratory Viruses, 13(March), pp. 309-318. doi: 10.1111/irv.12645.

Riskesdas (2018) HASIL UTAMA RISKESDAS 2018. Kementerian Kesehatan Badan Penelitian dan 
Pengembangan Kesehatan. Available at:

http://www.depkes.go.id/resources/do wnload/info-

terkini/materi_rakorpop_2018/Hasil

Riskesdas 2018.pdf.

Seeber, L. et al. (2017) 'Educating parents about the vaccination status of their children: A user-centered mobile application', Preventive Medicine Reports. The Author(s), 5, pp. 241250.

doi:

10.1016/j.pmedr.2017.01.002.

Seed, S. M. et al. (2016) 'Identification and review of mobile applications for travel medicine practitioners and patients', Journal of Travel Medicine, 23(4), pp. 1-6. doi: 10.1093/jtm/taw034.

Triana, V. (2016) 'Faktor yang berhubungan dengan pemberian imunisasi dasar lengkap pada bayi tahun 2015', Jurnal Kesehatan Masyarakat Andalas, 10(2), pp. 123-135.

WHO (2018) 2018 Assessment Report of the Global Vaccine Action Plan: Strategic Advisory Group of Experts on Immunization. Geneva: World Health Organization. Available at: https://www.who.int/immunization/gl obal_vaccine_action_plan/SAGE_G VAP_Assessment_Report_2018_EN. pdf.

WHO (2017) Immunization Achievements in South-East Asia: The Platform for Measless Elimination. New Delhi: World Health Organization for SouthEast Asia. Available at: https://apps.who.int/iris/handle/10665 1258759 .

Wilson, K. et al. (2016) 'Improving vaccine registries through mobile technologies: A vision for mobile enhanced Immunization information systems', Journal of the American Medical Informatics Association, 23(1), pp. 207-211. doi: 10.1093/jamia/ocv055.

Wilson, K., Atkinson, K. M. and Westeinde, J. (2015) 'Apps for immunization: Leveraging mobile devices to place the individual at the center of care', Human Vaccines and Immunotherapeutics, 11(10), pp. 2395-2399.

doi: 